\title{
Extended myectomy in the treatment of patients with hypertrophic obstructive cardiomyopathy
}

\author{
Mateusz Kuć ${ }^{1}$, Piotr Kołsut ${ }^{1}$, Jacek Różański ${ }^{1}$, Maciej Dąbrowski ${ }^{2}$, Mariusz Kłopotowski ${ }^{2}$, Magda Kumor ${ }^{3}$, \\ Mirosław Kowalski ${ }^{3}$, Natalia Kopyłowska ${ }^{4}$, Jarosław Kuriata ${ }^{1}$, Mariusz Kuśmierczyk ${ }^{1}$ \\ ${ }^{1}$ Department of Cardiosurgery and Transplantology, Institute of Cardiology, Warsaw, Poland \\ ${ }^{2}$ Department of Interventional Cardiology and Angiology, Institute of Cardiology, Warsaw, Poland \\ ${ }^{3}$ Department of Congenital Cardiac Defects, Institute of Cardiology, Warsaw, Poland \\ 4Students' Scientific Group at the Department of Cardiosurgery and Transplantology, Institute of Cardiology, Medical University \\ of Warsaw, Warsaw, Poland \\ Kardiochirurgia i Torakochirurgia Polska 2016; 13 (4): 300-304
}

\begin{abstract}
Introduction: Partial resection of the septal muscle is a wellestablished and effective method of surgical treatment for patients with hypertrophic obstructive cardiomyopathy (HOCM). The procedure is characterized by a low operative mortality rate and long-term clinical improvement that has been confirmed in numerous publications. Mitral insufficiency in patients with HOCM is mostly functional due to the effect of systolic anterior motion (SAM).

Aim: To present the early results of surgical treatment provided to HOCM patients and to compare the effectiveness of two surgical procedures: isolated myectomy and myectomy combined with mitral valve replacement.

Material and methods: The study analyzed a group of $49 \mathrm{pa}$ tients (20 women) with HOCM who underwent surgical treatment between 2012 and 2015. Isolated myectomy was performed in $67.25 \%(n=33)$ of patients, myectomy combined with mitral valve replacement in $30.61 \%(n=15)$, and $1(2.04 \%)$ patient underwent myectomy combined with mitral valvuloplasty (papillary muscle repositioning).

Results: A greater reduction of the left ventricular outflow tract (LVOT) gradient was observed in the population with concomitant mitral valve replacement in comparison to patients after isolated myectomy; the difference was statistically significant $(p=0.020)$. No significant correlation was observed between residual SAM and the grade of mitral regurgitation $(p=0.699)$ or between residual SAM and the LVOT gradient $(p=0.280)$. Conclusions: Surgical myectomy is a well-established, effective method of reducing increased LVOT gradients in patients with HOCM. Additional mitral valve replacement may be associated with greater reductions of the LVOT gradient in the early postoperative period. Valve replacement should be considered in patients with concomitant mitral valve degeneration and patients with narrowed left ventricular cavities.

Key words: hypertrophic cardiomyopathy, hypertrophic obstructive cardiomyopathy, myectomy.
\end{abstract}

\section{Streszczenie}

Wstęp: Częściowa resekcja mięśnia przegrody międzykomorowej to dobrze poznana i skuteczna metoda chirurgicznego leczenia pacjentów z kardiomiopatią przerostową z zawężeniem w drodze odptywu lewej komory (HOCM). Charakteryzuje się niską śmiertelnością okołooperacyjną, szybką i długotrwałą poprawą kliniczną, co zostało potwierdzone w licznych publikacjach. Niedomykalność zastawki mitralnej u pacjentów z HOCM jest w większości niedomykalnością funkcjonalną, wynikającą z zaburzonej hemodynamiki wewnątrz lewej komory oraz skurczowego ruchu przedniego płatka zastawki mitralnej (efekt SAM).

Cel: Przedstawienie wczesnych wyników leczenia operacyjnego HOCM w ośrodku autora w latach 2012-2015 oraz porównanie skuteczności zabiegu u pacjentów poddanych operacji miektomii oraz miektomii z jednoczesną wymianą zastawki mitralnej. Materiał i metody: Analizą objęto 49 chorych (20 kobiet) z HOCM, poddanych leczeniu operacyjnemu w latach 20122015. W analizowanej grupie $67,35 \%(n=33)$ stanowity izolowane miektomie, 30,61\% ( $n=15)$ miektomie z jednoczesną wymianą zastawki mitralnej, a 2,04\% $(n=1)$ miektomia z plastyką zastawki mitralnej.

Wyniki: Istotnie większą redukcję gradientu w drodze odpływu lewej komory (LVOT) $(p=0,020)$ odnotowano u pacjentów z jednoczesną wymianą zastawki mitralnej. Nie stwierdzono istotnej zależności między rezydualnym SAM i rezydualną niedomykalnością mitralną $(p=0,699)$ oraz rezydualnym SAM i rezydualnym gradientem w LVOT ( $p=0,280)$.

Wnioski: Chirurgiczna miektomia jest dobrze poznaną, skuteczną metodą redukcji gradientu w LVOT u chorych z HOCM. Poszerzenie zabiegu miektomii o wymianę zastawki mitralnej może się wiązać z większą redukcją gradientu w LVOT we wczesnym okresie pooperacyjnym. Wymianę zastawki należy rozważyć w przypadku wspótistnienia organicznej wady zastawki mitralnej oraz u pacjentów z koncentrycznym przerostem mięśnia i wąską jamą lewej komory.

Słowa kluczowe: kardiomiopatia przerostowa, kardiomiopatia przerostowa z zawężeniem w LVOT, miektomia.

Address for correspondence: Mateusz Kuć MD, Department of Cardiosurgery and Transplantology, Institute of Cardiology, 42 Alpejska St, 04-628 Warsaw, Poland, phone: +48 600681 086, e-mail: matheuskuc@gmail.com

Received: 3.08.2016, accepted: 10.11.2016. 


\section{Introduction}

Hypertrophic cardiomyopathy ( $\mathrm{HCM}$ ) is the most common genetically determined myocardial disease and is characterized by a varied clinical course. Due to the small population of affected patients and heterogeneous etiology, unequivocal treatment algorithms are lacking [1]. Elevated left ventricular outflow tract (LVOT) gradient at rest or after exercise is observed in $70 \%$ of HCM patients, while 20-30\% of patients are affected by significant gradient elevation at rest, which constitutes an unfavorable prognostic factor. Patients with elevated LVOT gradients often exhibit asymmetric hypertrophy of the interventricular septum (IVS). Surgical treatment should be considered in this group of patients if clinical symptoms (NYHA III-IV) or postexercise syncopes persist despite pharmacological therapy [1]. The first routine surgical method of proven efficacy was partial resection of the interventricular septal myocardium (myectomy) described by Andrew Glenn Morrow in 1960. The pathological mechanism associated with the development of elevated LVOT gradients is complex and includes mitral valve dysfunction. Interventricular septum hypertrophy disrupts LV hemodynamics [2], which results in motion of the anterior and/or posterior leaflet(s) in the direction of the LVOT $[2,3]$. The consequences of this may include an increase of the LVOT gradient [4], development of mitral insufficiency, and, ultimately, intensification of clinical symptoms. At the author's center, the surgical procedures most frequently performed in patients with hypertrophic obstructive cardiomyopathy (HOCM) are myectomy with papillary muscle mobilization [5], myectomy with concurrent mitral valve replacement described by Johnson in 1964 and Cooley in 1971, and myectomy with plastic repair of the subvalvular apparatus.

\section{Aim}

The aim of this study is to present the early results of HOCM surgical treatment at the author's center during the years 2012-2015 and to compare the efficacy of myectomy with that of myectomy with concurrent mitral valve replacement.

\section{Material and methods}

A group of $49 \mathrm{HOCM}$ patients operated on in the years 2012-2015 was analyzed retrospectively. Their age ranged from 17 to 85 years $(55.75 \pm 14.45)$; $41 \%$ were women $(n=$ $20)$ and $59 \%$ were men $(n=29)$. The data for analysis were obtained retrospectively from the IT system of the clinical unit where the patients were hospitalized. The calculations were made with IBM SPSS 23.0 software. Wilcoxon's test for dependent samples was used to assess the significance of the changes in the preoperative-postoperative measurements for quantitative and ordinal variables. Relationships between nominal variables and differences in distribution frequency were checked using a $\chi^{2}$ test. Comparisons between the two groups with regard to quantitative variables were made using the Mann-Whitney test as the conditions for parametric tests were not met. Values of $p<0.05$ were considered significant. The results are presented as maximal and minimal values, and means \pm SD. Mitral insufficiency was classified as mild, moderate, or severe in accordance with the 2003 guidelines of the American Society of Echocardiography [6]. Systolic anterior motion (SAM) was classified as present (if the anterior mitral leaflet (AML) was in contact with the interventricular septum), incomplete (if movement of the subvalvular apparatus or the AML in the direction of the IVS was observed), or no SAM. The procedures were performed with classic sternotomy and extracorporeal circulation. The superior and inferior venae cavae were cannulated in a typical fashion; a vent was introduced into the left ventricle through the right superior pulmonary vein. The first dose of blood cardioplegia was administered into the bulb of the aorta, and the subsequent doses were administered into the coronary ostia. All patients underwent myectomy. The IVS muscle was resected starting from 1-1.5 cm below the aortic annulus at the level of the middle of the right coronary leaflet, then left in the direction of the mitral valve, towards the apex, and right. The present additional chordae tendineae connecting the AML with the IVS were resected. In patients diagnosed with significant hypertrophy of the papillary muscles with adhesions to the IVS or the free wall of the left ventricle, mobilization of the muscles was performed by resecting their parabasal parts. In order to obtain better visualization of the IVS, the septum was pushed from the outside in towards the aortic annulus with a small gauze pad placed on curved Péan forceps. After the procedure was completed and extracorporeal circulation was ended, transesophageal echocardiography was conducted to assess the LVOT gradient, residual SAM, and mitral insufficiency. When the LVOT gradient was found to exceed $15-20 \mathrm{~mm} \mathrm{Hg}$, a redo procedure was performed with more extensive resection of the septal muscle. Mitral valve replacement was performed in patients with degenerative changes of the valve and in patients with concentric myocardial hypertrophy and narrow left ventricular cavities; in such cases, the subvalvular apparatus was resected.

\section{Results}

Of the analyzed patients, $67.35 \%(n=33)$ underwent isolated myectomy, 30.61\% ( $n=15)$ underwent myectomy with concurrent mitral valve replacement, and $2.04 \%(n=1)$ underwent myectomy with plastic repair of the mitral subvalvular apparatus. All the patients suffered from symptomatic hypertrophic cardiomyopathy resistant to pharmacological treatment. Maximal hypertrophy of the interventricular septum ranged from $15 \mathrm{~mm}$ to $36 \mathrm{~mm}$ (23.35 44.47). The patients were qualified for treatment based on the decision of the Heart Team, which included a cardiac surgeon, an interventional surgeon, and a cardiologist with experience in treating HCM patients. The statistical analysis omitted the patient who underwent concurrent subvalvular apparatus repair. Minimal preoperative LVOT gradient in the group undergoing myectomy and mitral valve replacement (MVR) was $90 \mathrm{~mm} \mathrm{Hg}$, maximal: $136 \mathrm{~mm} \mathrm{Hg}$ 
Tab. I. Pre- and postoperative gradients in both groups

\begin{tabular}{lcccccc} 
Variable & Number & Mean & Median & Minimum & Maximum & SD \\
GO MVR & 15 & 110 & 105 & 90 & 136 & 17.4 \\
\hline G1 MVR & 15 & 16 & 12 & 8 & 40 & 9.1 \\
\hline GO M & 33 & 100 & 90 & 40 & 255 & 45.3 \\
\hline G1 M & 33 & 27 & 23 & 7 & 52 & 14.2 \\
\hline
\end{tabular}

GO M - preoperative LVOT gradient in patients undergoing isolated myectomy, GO MVR - preoperative LVOT gradient in patients undergoing concurrent MVR, G1 M - postoperative LVOT gradient in patients undergoing isolated myectomy, G1 MVR - postoperative LVOT gradient in patients undergoing concurrent MVR.

Tab. II. Preoperative and postoperative gradient difference in both groups

\begin{tabular}{lllcllc} 
Variable & Mean & Median & Standard deviation & Minimum & Maximum & Number \\
M & -72.964 & -67.000 & 42.2200 & -205.0 & -20.0 & 33 \\
\hline MVR & -92.007 & -90.000 & 20.7840 & -120.4 & -53.0 & 15 \\
\hline Total & -78.915 & -78.500 & 37.7078 & -205.0 & -20.0 & 48 \\
\hline
\end{tabular}

$\mathrm{M}$ - population undergoing isolated myectomy, MVR - population undergoing concurrent mitral valve replacement.

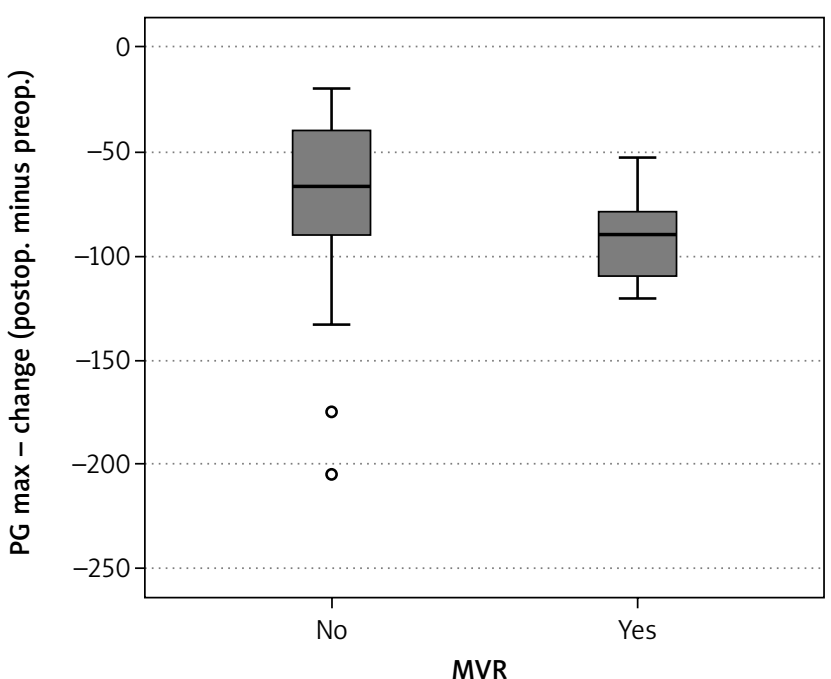

Fig. 1. Gradient reductions in the populations (postoperative minus preoperative)

MVR yes/no = concurrent mitral valve replacement/isolated myectomy.

(110 \pm 17.4 ). In the group undergoing isolated myectomy, the minimal gradient was $40 \mathrm{~mm} \mathrm{Hg}$, maximal: $255 \mathrm{~mm}$ $\mathrm{Hg}(100 \pm 45.3)$. After the surgical treatment, echocardiography was conducted during the same hospitalization, revealing the following distribution of LVOT gradients: in the group after myectomy + MVR: $\min .8 \mathrm{~mm} \mathrm{Hg}$, max. $40 \mathrm{~mm}$ $\mathrm{Hg}(16 \pm 9.1)$; in the group after isolated myectomy: min. $7 \mathrm{~mm} \mathrm{Hg}$, max. $52 \mathrm{~mm} \mathrm{Hg}(27 \pm 14.2)$ (Tab. I). The reduction of the LVOT gradient was as follows: in the group after myectomy + MVR: $\min .53 \mathrm{~mm} \mathrm{Hg}$, $\max .120 \mathrm{~mm} \mathrm{Hg}$ $(92 \pm 20.7)$; in the group after isolated myectomy: $\mathrm{min} .20 \mathrm{~mm}$ $\mathrm{Hg}$, max. 205 mm Hg (73 \pm 42.2$)$ (Tab. II). The gradient reduction was significantly more pronounced in the group of patients after MVR ( $p=0.020)$ (Fig. 1). The frequency of preoperative and postoperative mitral insufficiency in the group undergoing isolated myectomy is presented in Tables III and IV, respectively. Analysis with the Wilcoxon signed-rank test demonstrated a statistically significant improvement
Tab. III. Frequency table. Preoperative mitral insufficiency in the population undergoing isolated myectomy

\begin{tabular}{lcc} 
Mitral insufficiency & Frequency & Percentage \\
Mild & 14 & 42.4 \\
\hline Moderate & 18 & 54.5 \\
\hline Severe & 1 & 3.0 \\
\hline Total & 33 & 100.0 \\
\hline
\end{tabular}

Tab. IV. Frequency table. Postoperative mitral insufficiency in the population undergoing isolated myectomy

\begin{tabular}{lcc} 
Variable & Frequency & Percentage \\
No insufficiency & 9 & 27.3 \\
\hline Mild & 16 & 48.5 \\
\hline Moderate & 8 & 24.2 \\
\hline Total & 33 & 100.0 \\
\hline
\end{tabular}

Tab. V. Pre- and postoperative frequency of SAM and residual SAM (RSAM)

\begin{tabular}{lcccc} 
Variable & \multicolumn{2}{c}{ SAM } & \multicolumn{2}{c}{ RSAM } \\
\cline { 2 - 5 } No & Frequency & Percentage & Frequency & Percentage \\
\hline Incomplete & 0 & 6.1 & 19 & 57.6 \\
\hline Yes & 31 & 93.9 & 10 & 30.3 \\
\hline Total & 33 & 100.0 & 33 & 12.1 \\
\hline
\end{tabular}

of mitral insufficiency ( $p=0.001)$. The pre- and postoperative frequency and degree of SAM are presented in Table V. A significant reduction in SAM after myectomy was demonstrated $(p<0.0005)$. The analysis of postoperative data showed no significant correlations between the variables: residual SAM and Gmax in the LVOT $(p=0.280)$ and residual SAM and residual mitral insufficiency $(p=0.966)$. The hospitalization of patients after isolated myectomy lasted $12 \pm 9$ days on average; concurrent mitral valve replacement was associated with longer hospitalization: $29 \pm 48$ days 
on average. Postoperative cardiac dysrhythmias were observed in $18 \%$ of patients $(n=6)$ after isolated myectomy. No pacemakers were implanted; however, $27 \%$ of the patients $(n=9)$ had already been implanted with pacemakers before the procedure. One patient underwent concurrent $C A B G$, and one patient was implanted with a prosthesis of the ascending aorta due to an iatrogenic injury. Among the patients undergoing concurrent myectomy and MVR, cardiac dysrhythmias occurred in $47 \%(n=7)$; pacemaker implantation was required in $40 \%(n=6)$, and 1 patient had already received a pacemaker before the procedure. Additionally, the aortic valve was replaced in $13 \%$ of the patients $(n=2)$, and 1 patient underwent tricuspid valvuloplasty. There were no intra- or postoperative deaths in the analyzed population.

\section{Discussion}

Myectomy is the standard method of surgical HOCM management; however, the partial resection of the basal segment of the IVS described by Morrow et al. can be associated with an elevated residual LVOT gradient [7]. In the analyzed population undergoing extended myectomy, the postoperative LVOT gradient ranged from $7 \mathrm{~mm} \mathrm{Hg}$ to $52 \mathrm{~mm} \mathrm{Hg}(27 \pm 14.2)$. Dynamic elevation of the LVOT gradient is associated with SAM of the mitral valve $[2,4]$. However, the analyzed data did not show such an association with regard to the residual LVOT gradient during the period immediately after the surgery $(p=0.280)$. More than mild was found in $24.2 \%$ of patients $(n=8)$, but no influence of SAM on valve insufficiency was demonstrated ( $p=0.966$ ). Johnson (in 1964) and Cooley (in 1971) were proponents of performing myectomy with concurrent mitral valve replacements, a method that offered long-term and predictable effects [8, 9]. Despite satisfactory treatment outcomes, the method has become rather controversial [10]. Between 2012 and 2015, we performed 15 myectomies with mitral valve replacement (30.61\%) at our center. The procedure was performed in patients diagnosed with degenerative mitral valve lesions or significant concentric myocardial hypertrophy in the middle segments and narrow left ventricular cavities; the subvalvular apparatus was resected each time. The method achieved a significantly better reduction of the LVOT gradient in the early postoperative period in comparison to isolated myectomy $(p=0.020)$, but the procedure was associated with a greater number of complications and longer hospitalization. As the methods of cardiac imaging developed, enabling better understanding of the pathological mechanism of dynamic LVOT gradient elevation and the causes of the often concomitant MI, the dominant role of the Venturi effect was called into question [2]. Some large centers treating HOCM patients have proposed to employ more extensive myectomy with papillary muscle mobilization [5, 11-14]; others postulate the performance of concurrent mitral valvuloplasty $[11,12,15,16]$. The long-term results of both strategies are equally satisfactory. It has also been demonstrated that failures defined as residual elevated LVOT gradients were associated with insufficient LV muscle resection [17, 18]. In the present study, we analyzed the results of postoperative transthoracic echocardiography in patients undergoing HOCM surgery. Two groups were distinguished: patients undergoing isolated myectomy and patients undergoing myectomy with mitral valve replacement. A significantly more pronounced reduction in the LVOT gradient was observed in the latter group $(p=0.020)$. Concurrent mitral valve replacement was associated with longer hospitalization and a greater number of complications.

\section{Conclusions}

Surgical myectomy is a well-known, efficacious method of reducing the LVOT gradient in HOCM patients. Supplementing myectomy with mitral valve replacement can result in more pronounced LVOT gradient reduction during the early postoperative period. Valve replacement should be considered in patients with concomitant organic defects of the mitral valve and in patients with concentric muscle hypertrophy and narrow left ventricular cavities.

\section{Disclosure}

Authors report no conflict of interest.

\section{References}

1. 2014 ESC Guidelines on diagnosis and management of hypertrophic cardiomyopathy. Eur Heart J 2014; 35: 2733-2779.

2. Ro R, Halpern D, Sahn DJ, Homel P, Arabadjian M, Lopresto C, Sherrid MV. Vector flow mapping in obstructive hypertrophic cardiomyopathy to assess the relationship of early systolic left ventricular flow and the mitral valve. J Am Coll Cardiol 2014; 64: 1984-1995.

3. Shah PM, Gramiak R, Kramer DH. Ultrasound localization of left ventricular outflow obstruction in hypertrophic obstructive cardiomyopathy. Circulation 1969; 40: 3-11.

4. Yu EH, Omran AS, Wigle ED, Williams WG, Siu SC, Rakowski H. Mitral regurgitation in hypertrophic obstructive cardiomyopathy: relationship to obstruction and relief with myectomy. J Am Coll Cardiol 2000; 36: 2219-2225.

5. Dearani JA, Ommen SR, Gersh BJ, Schaff HV, Danielson GK. Surgery insight: Septal myectomy for obstructive hypertrophic cardiomyopathy - the Mayo clinic experience. Nat Clin Pract Cardiovasc Med 2007; 4: 503-512.

6. Zoghbi WA, Enriquez-Sarano M, Foster E, Grayburn PA, Kraft CD, Levine RA, Nihoyannopoulos P, Otto CM, Quinones MA, Rakowski H, Stewart WJ, Waggoner A, Weissman NJ; American Society of Echocardiography. Recommendations for evaluation of the severity of native valvular regurgitation with two-dimensional and Doppler echocardiography. J Am Soc Echocardiogr 2003; 16: 777-802.

7. Morrow AG, Fogarty TJ, Hannah H 3rd, Braunwald E. Operative treatment in idiopathic hypertrophic subaortic stenosis. Techniques, and the results of preoperative and postoperative clinical and hemodynamic assessments. Circulation 1968; 37: 589-596.

8. Stassano P, Tommaso L, Triggiani D, Contaldo A, Gagliardi C, Spampinato N. Mitral valve replacement and limited myectomy for hypertrophic obstructive cardiomyopathy. Tex Heart Inst J 2004; 31: 137-142.

9. Cooley DA, Leachman RD, Hallman GL, Gerami S, Hall RJ. Idiopathic hypertrophic subaortic stenosis. Surgical treatment including mitral valve replacement. Arch Surg 1971; 103: 606-609.

10. Stassano P, Di Tommaso L, Triggiani D, Contaldo A, Gagliardi C, Spampinato N. Mitral valve replacement and limited myectomy for hypertrophic obstructive cardiomyopathy: a 25-year follow-up. Tex Heart Inst J 2004; 31: 137-142.

11. Balaram SK, Tyrie L, Sherrid MV, Afthinos J, Hillel Z, Winson G, Swistel DG Resection-plication-release for hypertrophic cardiomyopathy: clinical and echocardiographic follow-up. Ann Thorac Surg 2008; 86: 1539-1544, discussion 1544-1545. 
12. Schoendube FA, Klues HG, Reith S, Flachskamp FA, Hanrath P, Messmer BJ. Long-term clinical and echocardiographic follow-up after surgical correction of hypertrophic obstructive cardiomyopathy with extended myectomy and reconstruction of the subvalvular mitral apparatus. Circulation 2001; 104: E32-E33.

13. Woo A, Williams WG, Choi R, Wigle ED, Rozenblyum E, Fedwick K, Siu S, Ralph-Edwards A, Rakowski H. Clinical and echocardiographic determinants of long-term survival after surgical myectomy in obstructive hypertrophic cardiomyopathy. Circulation 2005; 111: 2033-2041.

14. Ommen SR, Maron BJ, Olivotto I, Maron MS, Cecchi F, Betocchi S, Gersh BJ, Ackerman MJ, McCully RB, Dearani JA, Schaff HV, Danielson GK, Tajik AJ, Nishimura RA. Long-term effects of surgical septal myectomy on survival in patients with obstructive hypertrophic cardiomyopathy. J Am Coll Cardiol 2005; 46: 470-476.

15. Vriesendorp PA, Schinkel AF, Soliman OI, Kofflard MJ, de Jong PL, van Herwerden LA, Ten Cate FJ, Michels M. Long-term benefit of myectomy and ante- rior mitral leaflet extension in obstructive hypertrophic cardiomyopathy. Am J Cardiol 2015; 115: 670-675.

16. Moravsky G, Bruchal-Garbicz B, Jamorski M, Ralph-Edwards A, Gruner C, Williams L, Woo A, Yang H, Laczay B, Rakowski H, Carasso S. Myocardial mechanical remodeling after septal myectomy for severe obstructive hypertrophic cardiomyopathy. J Am Soc Echocardiogr 2013; 26: 893-900.

17. Cho YH, Quintana E, Schaff HV, Nishimura RA, Dearani JA, Abel MD, Ommen S. Residual and recurrent gradients after septal myectomy for hypertrophic cardiomyopathy - mechanisms of obstruction and outcomes of reoperation. J Thorac Cardiovasc Surg 2014; 148: 909-915.

18. Minakata K, Dearani JA, Schaff HV, O'Leary PW, Ommen SR, Danielson GK. Mechanisms for recurrent left ventricular outflow tract obstruction after septal myectomy for obstructive hypertrophic cardiomyopathy. Ann Thorac Surg 2005; 80: 851-856 